\begin{tabular}{|c|c|c|}
\hline $\begin{array}{c}\text { Volume 1, Nomor 2, p 65-72 } \\
\text { Oktober 2017 }\end{array}$ & ISSN: 2502-6496 (Print) \\
\hline
\end{tabular}

\title{
Analisis kepadatan bakteri coliform di Sungai Siak (sekitar perumahan sari residence Kota Pekanbaru)
}

\author{
Arief Mubyarso $^{1}$, Yusni Ikhwan Siregar ${ }^{2}$, Sofyan Husein Siregar ${ }^{2}$ \\ ${ }^{1}$ PT. Mahkota Hutama Properti. \\ ${ }^{2}$ Ilmu Lingkungan Program Pascasarjana Universitas Riau.
}

\begin{abstract}
Faecal coliforms are indicative bacteria of fecal contamination. If the bacteria are found in the waters so that the waters has been polluted and can not be used as a source of drinking water. The research has been conducted from April to June 2014 at Sari Residence Housing which located in Siak riverbanks by using survey method. Densitydata of water coliform bacteria the preliminary test and assertion test in the laboratory according to SNI 2897-2008. Data analysis is using ANOVA statistics and compared with the water quality standards according to the Indonesian Government Regulation No. 82 year 2001 on the Management of Water Quality and Water Pollution ControlClass I and Class II. The results showed that the density of coliform bacteria in the Siak River (around Sari Residence Housing Pekanbaru city) ranged between 11267-15650jml/ 100mL and pass the drinking water quality standards and require special handlingfor the use of water. Siak River water (around Sari Residence Housing Pekanbaru city)not feasible for consumption according to PP 82 year 2001 class I and II on the drinkingwater requirements of $1000 \mathrm{jml} / 100 \mathrm{~mL}$ and $5000 \mathrm{jml} / 100 \mathrm{~mL}$
\end{abstract}

Keywords: Analysis; Coliform Bacteria; River

Peningkatan kegiatan pembangunan di berbagai bidang secara langsung ataupun tidak langsung akan mempunyai dampak terhadap kerusakan lingkungan termasuk didalamnya pencemaran sungai. Aktivitas masyarakat di sekitar bantaran sungai tentunya akan berpengaruh terhadap kualitas air sungai, karena limbah yang dihasilkan dari aktivitas masyarakat tersebut bila dibuang langsung ke perairan sungai bila melebihi kemampuan sungai untuk membersihkan diri sendiri (self purification), maka timbul permasalahan yang serius yaitu pencemaran perairan, sehingga berpengaruh negatif terhadap kehidupan biota perairan dan kesehatan masyarakat yang memanfaatkan air sungai tersebut (Kasry, 2005)

Aktivitas penduduk yang semakin meningkat di sepanjang aliran Sungai Siak telah mempengaruhi kualitas air sungai, seperti perumahan Sari Residence yang berada di pinggiran sungai Siak masih membuang air limbah domestik perumahannya terutama limbah MCK yang resapannya dibuang ke parit jalan atau gorong-gorong melalui sistem drainase yang terintegrasi ke sungai Siak.

Sungai-sungai yang ada di Pekanbaru, yaitu sungai Siak, sungai Sail, sungai Batak dan sungaisungai kecil lainnya sudah tercemar berat. Kandungan bakteri E.coli (Escherichia coli) sudah mencapai 270.000/mililiter air, sementara ambang baku mutu hanya 1000 permililiter air. Bahaya dari bakteri $E$. coli bisa menyerang kulit manusia dan pencernaan atau diare. Sehingga wajar kalau selama ini masyarakat yang masih bergantung di Sungai Siak dan sejumlah Sungai lainnya di Pekanbaru seringkali terserang diare (Anonim, 2013).

\section{METODE PENELITIAN}

Penelitian ini dilaksanakan pada bulan April hingga Juni 2014 di perairan Sungai Siak sekitar Perumahan Sari Residence Kota Pekanbaru. Wilayah Sungai Siak sekitar Perumahan Sari Residence dalam wilayah administrasi Kota Pekanbaru di pilih karena saluran pembuangan limbah cair perumahan yang terintegrasi ke Sungai Siak, sehingga di duga memiliki kepadatan pencemar yang relatif besar terutama bila ditinjau dari parameter bakteri coliform.

Alat digunakan pada penelitian ini yaitu : GPS merek Garmin, thermometer air raksa, secci disk, current drogue, $\mathrm{pH}$ meter, botol pengambil air sampel dengan pemberat, botol steril. Ember, gayung, alat tulis, kamera, luxmeter, botol steril, erlenmeyer, beker glass, gelas ukur, tabung reaksi, tabung durham, rak tabung, kapas penutup, cawan petri, spatula, autoklaf, oven/inkubator, bunsen, makro dan mikropipet, ose, mikroskop, pinset, gelas objek, hot plate, kertas label dan aluminium foil. Bahan-bahan yang digunakan pada penelitian ini antara lain: sampel air, akuades steril, alkohol 70\%, MnSO4, KOHKI, larutan $\mathrm{H} 2 \mathrm{SO} 4$ pekat, larutan Natrium tiosulfat 0,025 N, media Lactose Broth (LB), media Briliant Green Lactose Bile Broth (BGLBB), media Eosine Metilene Blue (EMB), media Triple Sugar Iron Agar (TSIA), media Sulphite Indole 
Metility (SIM), media Simon Sitrat Agar, Glukosa Of Basal Media, media NA, larutan Oksidase dan katalase (H2O2 3\%), pewarnaan gram, minyak emersi, larutan Kovac's dan parafin.

Lokasi sampling ditentukan secara purposive random sampling dengan mempertimbangkan lokasi masukan sumber bahan pencemar bakteri coliform dengan kegiatan yang diduga berpengaruh besar terhadap kepadatan bakteri coliform pada perairan sungai Siak sekitar perumahan Sari Residence sebagai objek penelitian. Stasiun sampling ditetapkan sebanyak 5 (lima) stasiun. Stasiun 1 diprediksi merupakan sumber masukan bahan pencemar dari kegiatan limbah cair domestik perumahan Sari Residence Kota Pekanbaru. Stasiun 1 berlokasi disepanjang aliran parit setelah gorong-gorong perumahan Sari Residence sebelum masuk ke badan air sungai Siak. Penempatan stasiun 2 berjarak \pm 124 meter dari stasiun 1 yang berlokasi di sekitar perumahan Sari Residence yang diprediksi menerima masukan bahan pencemar dari kegiatan limbah cair domestik perumahan Sari Residence melalui aliran parit setelah gorong-gorong perumahan Sari Residence yang terintegrasi langsung ke badan air sungai Siak. Stasiun 3 berjarak \pm 600 meter dari stasiun 2 mengarah ke hilir sungai yang berlokasi di sekitar PDAM. Stasiun 4 berjarak \pm 450 meter dari stasiun 2 mengarah ke hulu sungai yang berlokasi di sekitar perkebunan sawit masyarakat dan bekas kilang kau serta stasiun 5 yang berlokasi di ujung gorong-gorong perumahan Sari Residence di duga merupakan sumber pencemar utama dari kegiatan limbah cair domestik perumahan Sari Residence.

Pengukuran kualitas air di sekitar lokasi sampling dilakukan secara visual (untuk warna perairan), secara fisika (suhu, kecerahan dan kecepatan arus) dan kimia ( $\mathrm{pH}$ dan oksigen terlarut) serta secara bakteriologis adalah kepadatan bakteri coliform. Pengukuran kualitas perairan secara insitu dilakukan bersamaan pada waktu pengambilan sampel pada masing-masing stasiun.

Berdasarkan SNI 06-2413-2002 serta dibantu oleh tenaga ahli laboratorium, parameter yang diukur secara langsung adalah kecerahan, suhu, kecepatan arus, $\mathrm{pH}$ dan DO. Pengukuran debit air dilakukan dengan mengukur luas penampang dan kecepatan arus air per menit. Kecepatan arus diukur pada permukaan perairan dengan cara memberikan tali pada current drogue dan diletakkan pada permukaan perairan kemudian diukur jarak tempuh current drogue tersebut dalam satuan waktu, yaitu ${ }^{\mathrm{m}} /$ detik dari jarak awal diletakkan.

Penentuan nilai kepadatan bakteri coliform dihitung sesuai SNI 2897-2008. Banyaknya coliform yang terdapat dalam bahan uji diinterpretasikan dengan mencocokkan kombinasi jumlah tabung yang memperlihatkan hasil positif, berdasarkan tabel nilai MPN. Kombinasi yang diambil dimulai dari pengenceran tertinggi yang masih menghasilkan semua tabung positif, sedangkan pada pengenceran berikutnya terdapat tabung yang negatif. Kombinasi yang diambil terdiri dari tiga pengenceran. Berdasarkan SNI 2897-2008, pemeriksaan terhadap bakteri Escherichia coli dilakukan dalam 4 tahapan, yaitu tes pendahuluan (persumtive test), tes penegasan (confirmative test), tes pelengkap (complete test) dan karakterisasi $E$. coli. Pada penelitian ini hanya dilakukan 2 tahapan dalam menghitung kepadatan bakteri Coliform.

Data dianalisis dengan menggunakan analisis statistik (ANOVA) untuk melihat perbandingan antar stasiun. Data parameter kualitas air dibandingkan dengan baku mutu kualitas air sesuai dengan standar kualitas air bersih menurut Peraturan Pemerintah Republik Indonesia No. 82 Tahun 2001 tentang Pengelolaan Kualitas Air dan Pengendalian Pencemaran Air Kelas I, yaitu air yang peruntukannya dapat digunakan untuk air baku air minum dan atau peruntukan lain yang mempersyaratkan mutu air yang sama dengan kegunaan tersebut dan kelas II, yaitu air yang digunakan untuk prasarana/sarana rekreasi air, pembudidayaan ikan tawar, peternakan, mengairi pertanaman dan atau peruntukan lain yang mempersyaratkan mutu air yang sama dengan kegunaan tersebut.

\section{HASIL DAN PEMBAHASAN}

Perumahan Sari Residence yang memiliki area sekitar 21 ha dengan jumlah penghuni saat ini sekitar $116 \mathrm{KK}$ masih melakukan pembuangan limbah domestik secara konvensional dimana limbah cair domestik yang berasal dari rumah dialirkan melalui parit atau gorong-gorong menuju Sungai Siak di Sekitar Perumahan Sari Residence.

Dari hasil pengamatan dilapangan menunjukkan bahwa keadaan cuaca perairan Sungai Siak di Sekitar Perumahan Sari Residence selama pengambilan sampel pada ulangan pertama dalam kondisi mendung dengan perkiraan suhu udara $\pm 30{ }^{\circ} \mathrm{C}$. Sedangkan ulangan ke-2 dan 3 cuaca dalam keadaan cerah dengan perkiraan suhu udara berkisar antara $31-32^{\circ} \mathrm{C}$. Perbedaan cuaca dalam pengambilan sampel menyebabkan terjadinya perbedaan kondisi umum perairan Sungai Siak di Sekitar Perumahan Sari 
Residence meskipun tidak terlalu signifikan. Perbedaan cuaca sangat terkait dengan pergerakan air akibat perbedaan suhu permukaan dan dasar perairan. Pada cuaca yang mendung massa air yang lebih dalam yang diprediksi banyak mengandung beban pencemar akan naik ke permukaan karena adanya pembalikan massa air dan perbedaan suhu. Effendi (2003) menyatakan bahwa jumlah radiasi yang mencapai permukaan perairan sangat dipengaruhi oleh awan, ketinggian permukaan air (altitute), letak geografis dan musim. Cahaya matahari yang mencapai permukaan perairan sebagian diserap dan sebagian direfleksikan kembali. Penetrasi cahaya ke dalam air sangat dipengaruhi oleh intensitas dan sudut datang cahaya, kondisi permukaan air dan bahan-bahan yang terlarut dan tersuspensi di dalam air (Boyd, 1998). Sudut datang tepat pada $90{ }^{\circ} \mathrm{C}$ (terjadi pada sekitar pukul $12.00 \mathrm{WIB}$ ) intensitas cahaya yang dipantulkan sekitar $1,5-2,0 \%$, sementara saat penelitian ini berlangsung yaitu pada pukul $10.00-15.00 \mathrm{WIB}$, sehingga diasumsikan penetrasi cahaya ke badan perairan relatif besar terkecuali pada saat pengambilan sampel pada ulangan pertama, karena kondisi cuaca dalam keadaan mendung. Kondisi cuaca tersebut akan mempengaruhi suhu udara disekitarnya. Suhu udara pada saat penelitian berlangsung masih berada pada kisaran normal, yaitu $30-32{ }^{\circ} \mathrm{C}$. Suhu udara akan berpengaruh pada suhu badan air. Perubahan suhu perairan tentunya akan berpengaruh terhadap proses fisika dan kimia perairan.

Suhu rata-rata perairan Sungai Siak di Sekitar Perumahan Sari Residence selama penelitian di tiga stasiun kecuali stasiun 1 dan 5 yang diduga merupakan sumber pencemar berkisar antara $31,2-31,4{ }^{\circ} \mathrm{C}$. Stasiun 1 yang di duga sebagai sumber pencemar rata-rata sebesar $31,5^{\circ} \mathrm{C}$, Stasiun 2 rata-rata sebesar 31,4 ${ }^{\circ} \mathrm{C}$, Stasiun 3 rata-rata sebesar $31,2333{ }^{\circ} \mathrm{C}$, Stasiun 4 rata-rata sebesar $31,3{ }^{\circ} \mathrm{C}$ dan Stasiun 5 yang di duga sebagai sumber pencemar rata-rata sebesar $31,1333{ }^{\circ} \mathrm{C}$. Dari tabel Test Of Homogeneity Of Variances terlihat bahwa hasil uji menunjukkan bahwa varian kelima stasiun sama $(\mathrm{P}$-value $=0,007)$. Hasil uji one way ANOVA yang telah dilakukan mengindikasikan bahwa nilai $\rho=0,819$ lebih besar daripada nilai kritik $\alpha=$ 0,05 sehingga tidak ada perbedaan rata-rata suhu berdasarkan kelima stasiun tersebut.

Kisaran suhu perairan Sungai Siak di Sekitar Perumahan Sari Residence masih berada pada kisaran level normal, sebagaimana baku mutu Peraturan Pemerintah No. 82 Tahun 2011, yaitu $28,17^{\circ} \mathrm{C}$ untuk baku mutu suhu minimal dan $34,17{ }^{\circ} \mathrm{C}$ untuk baku mutu suhu maksimal. Perubahan suhu sangat berpengaruh terhadap proses fisika, kimia dan biologi. Setiap organisme akuatik menginginkan kisaran suhu tertentu (batas atas dan bawah) yang sesuai dengan pertumbuhannya. Dengan kata lain aktivitas biologis - fisiologis di dalam ekosistem perairan sangat dipengaruhi oleh suhu. Benoit (1971) menyatakan kenaikan suhu akan meningkatkan laju metabolisme pada organisme. Meningkatnya laju metabolisme, akan menyebabkan konsumsi oksigen meningkat dan selanjutnya akan menurunkan kelarutan oksigen perairan. Pola temperatur ekosistem perairan dipengaruhi oleh berbagai faktor seperti intensitas cahaya matahari, pertukaran panas antara perairan dengan udara sekitarnya dan ketinggian geografis (Wetzel, 1975).

Hasil pengukuran kecerahan rata-rata di perairan Sungai Siak di Sekitar Perumahan Sari Residence Kota Pekanbaru di tiga stasiun kecuali stasiun 1 dan 5 yang diduga sumber pencemar berkisar antara 30,3 $-30,7 \mathrm{~cm}$. Stasiun 1 yang diduga sebagai sumber pencemar kecerahan rata-rata sebesar $0,00 \mathrm{~cm}$, Stasiun 2 rata-rata sebesar $39,5 \mathrm{~cm}$, Stasiun 3 rata-rata sebesar $43,5 \mathrm{~cm}$, Stasiun 4 rata-rata sebesar 44,3333 cm dan Stasiun 5 rata-rata $0,00 \mathrm{~cm}$. Dari tabel Test Of Homogeneity Of Variances terlihat bahwa hasil uji menunjukkan bahwa varian ketiga stasiun sama $(P$-value $=0,009)$, sehingga uji anova valid untuk menguji hubungan ini. Hasil uji one way ANOVA yang telah dilakukan mengindikasikan bahwa nilai $\rho=0,000$ lebih kecil daripada nilai kritik $\alpha=0,05$ sehingga ada perbedaan rata-rata kecerahan berdasarkan kelima stasiun tersebut. Karena hasil uji Anova menunjukkan adanya perbedaan, maka uji selanjutnya adalah melihat stasiun mana saja yang berbeda. Dari Test Of Homogeneity Of Variances menghasilkan bahwa varian kelima stasiun tersebut sama, maka uji lanjut (Post Hoc Test) yang digunakan adalah uji Boferroni untuk menunjukkan adanya perbedaan kecerahan rata-rata.

Kawasan yang paling rendah nilai kecerahannya adalah Stasiun 2 yang mewakili wilayah Sungai Siak di Sekitar Perumahan Sari Residence. Hal ini disebabkan Stasiun 2 adalah kawasan yang diduga paling besar menerima limbah dari kegiatan domestik Perumahan Sari Residence sehingga menurunkan nilai kecerahan. Pada Stasiun 3 yang berlokasi disekitar PDAM mengarah ke hilir sungai diprediksi juga menerima masukan bahan pencemar dari kegiatan domestik, tetapi nilai kecerahan relatif lebih baik dari nilai kecerahan pada Stasiun 2. Sedangkan Stasiun 4 yang berlokasi di sekitar perkebunan sawit masyarakat dan bekas kilang kayu mengarah ke hulu sungai diprediksi tidak menerima masukan bahan pencemar dari kegiatan domestik, sehingga nilai kecerahan relatif lebih baik.

Tingginya bahan-bahan yang masuk ke perairan Sungai Siak (Sekitar Perumahan Sari Residence) terutama disekitar Stasiun 2 yang menyebabkan rendahnya kecerahan perairan diprediksi disebabkan oleh dua hal. Pertama karena meningkatnya hunian dan aktivitas yang dilakukan masyarakat di sepanjang 
bantaran sungai yang disebabkan oleh meningkatnya jumlah penduduk. Kedua meningkatnya intensitas kegiatan industri dan pelayaran. Secara umum peningkatan jumlah penduduk akan memerlukan ruang untuk tempat tinggal dan usaha. Akibat keterbatasan lahan yang tersedia menyebabkan masyarakat menempati wilayah bantaran sungai sehingga mengakibatkan daerah aliran sungai yang berfungsi mengatur tata air menjadi semakin sempit dan cenderung menjadi keruh dan kotor (Hak, 2012).

Kecepatan arus akan mempengaruhi faktor lingkungan seperti oksigen terlarut, suhu, karbondioksida, jumlah makanan, karakteristik organisme perairan, tingkat sedimentasi dan pencemaran (Hamidy, 1993). Dari hasil pengukuran diperoleh nilai rata-rata kecepatan arus perairan Sungai Siak Sekitar Perumahan Sari Residence di tiga stasiun kecuali stasiun 1 dan 5 yang diduga sebagai sumber pencemar berkisar antara $0,07-0,19 \mathrm{~m} / \mathrm{dtk}$.

Dari tabel Descriptives nampak bahwa Stasiun 1 yang diduga sebagai sumber pencemar kecepatan arus rata-rata sebesar $0,00 \mathrm{~m} / \mathrm{dtk}$, Stasiun 2 rata-rata sebesar $0,07 \mathrm{~m} / \mathrm{dtk}$, Stasiun 3 rata-rata sebesar 0,12 $\mathrm{m} / \mathrm{dtk}$, Stasiun 4 rata-rata sebesar 0,1933 $\mathrm{m} / \mathrm{dtk}$ dan Stasiun 5 rata-rata 0,00 $\mathrm{m} / \mathrm{dtk}$. Dari tabel Test Of Homogeneity Of Variances terlihat bahwa hasil uji menunjukkan bahwa varian ketiga stasiun sama (P-value = 0,001 ), sehingga uji anova valid untuk menguji hubungan ini. Hasil uji one way ANOVA yang telah dilakukan mengindikasikan bahwa nilai $\rho=0,002$ lebih kecil daripada nilai kritik $\alpha=0,05$ sehingga ada perbedaan rata-rata kecepatan arus berdasarkan kelima stasiun tersebut. Karena hasil uji Anova menunjukkan adanya perbedaan, maka uji selanjutnya adalah melihat stasiun mana saja yang berbeda. Dari Test Of Homogeneity Of Variances menghasilkan bahwa varian kelima stasiun tersebut sama, maka uji lanjut (Post Hoc Test) yang digunakan adalah uji Boferroni untuk menunjukkan adanya perbedaan kecepatan arus.

Nilai DO rata-rata perairan Sungai Siak di Sekitar Perumahan Sari Residence di tiga stasiun kecuali stasiun 1 dan 5 yang diduga sumber pencemar berkisar 2,11 - 2,13 mg/L. Dari tabel Descriptives nampak bahwa Stasiun 1 yang diduga sebagai sumber pencemar DO rata-rata sebesar 0,2933 mg/l, Stasiun 2 ratarata sebesar 2,1267 mg/1, Stasiun 3 rata-rata sebesar 2,12 mg/l, Stasiun 4 rata-rata sebesar 2,11 mg/1 dan Stasiun 5 yang juga diduga sumber pencemar rata-rata $0,2867 \mathrm{mg} / 1$. Dari tabel Test Of Homogeneity Of Variances terlihat bahwa hasil uji menunjukkan bahwa varian ketiga stasiun sama ( $\mathrm{P}$-value $=0,078$ ), sehingga uji anova valid untuk menguji hubungan ini. Hasil uji one way ANOVA yang telah dilakukan mengindikasikan bahwa nilai $\rho=0,000$ lebih kecil daripada nilai kritik $\alpha=0,05$ sehingga ada perbedaan rata-rata kecepatan arus berdasarkan kelima stasiun tersebut. Karena hasil uji Anova menunjukkan adanya perbedaan, maka uji selanjutnya adalah melihat stasiun mana saja yang berbeda. Dari Test Of Homogeneity Of Variances menghasilkan bahwa varian kelima stasiun tersebut sama, maka uji lanjut (Post Hoc Test) yang digunakan adalah uji Boferroni untuk memperlihatkan bahwa semua stasiun yang menunjukkan adanya perbedaan DO.

Nilai DO rata-rata perairan Sungai Siak di Sekitar Perumahan Sari Residence menunjukkan hasil yang sangat rendah, yaitu berkisar 2,11 $-2,13 \mathrm{mg} / \mathrm{L}$ yang berarti bahwa nilai DO sudah berada pada kondisi kekurangan oksigen terlarut. Hal ini menunjukkan bahwa di perairan Sungai Siak di Sekitar Perumahan Sari Residence konsumsi oksigen sangat tinggi sebagai akibat dari terjadinya peningkatan jumlah limbah organik yang berasal dari kegiatan di badan sungai yang berasal dari limbah domestik dari daerah sekitarnya. Merujuk pada nilai baku mutu menurut Peraturan Pemerintah No. 82 Tahun 2001 Kelas I dan II, diketahui bahwa DO perairan Sungai Siak di Sekitar Perumahan Sari Residence sudah tidak memenuhi baku mutu yang ditetapkan.

Hasil pengukuran konsentrasi DO Perairan Sungai Siak di Sekitar Perumahan Sari Residence ini tentunya harus diwaspadai karena selain nilai konsentrasi telah berada pada level mengkhawatirkan juga telah terjadi hampir di seluruh wilayah perairan yang menjadi lokasi penelitian. Hal ini dapat dilihat dari rendahnya konsentrasi DO baik pada stasiun 2, 3 dan 4. Merujuk pada hasil penelitian ini, maka diprediksi telah terjadi penurunan dan kerusakan kualitas lingkungan di bagian Hulu maupun Hilir Sungai Siak (Sekitar Perumahan Sari Residence). Hasil penelitian ini diperkuat oleh Putra (2009) yang menyatakan bahwa luas perkebunan sawit di DAS Tapung Kiri telah mencapai luasan 87.996 Ha.

Selain akibat kerusakan di bagian Hulu Sungai Siak di Sekitar Perumahan Sari Residence, rendahnya kandungan oksigen di perairan Sungai Siak juga disebabkan oleh proses pengkayaan unsur hara atau zat pencemar berupa limbah domestik yang menyebabkan tingginya aktivitas bakteri pengurai yang menggunakan DO perairan. Hal ini dapat dilihat dari semakin rendahnya konsentrasi DO pada stasiun 2, 3 dan 4. Kandungan limbah organik perairan Sungai Siak di Sekitar Perumahan Sari Residence terutama disekitar stasiun 2 diprediksi berasal dari aktivitas limbah domestik. Tingginya buangan limbah baik oleh industri maupun domestik perkotaan tanpa pengolahan terlebih dahulu akan menyumbangkan limbah 
dalam bentuk padatan tersuspensi dan bahan buangan yang memerlukan oksigen dalam proses penguraian yang dilakukan oleh bakteri. Hal ini akan menyebabkan terhambatnya regenerasi oksigen karena terjadi konsumsi oksigen oleh mikroorganisme untuk merombak bahan bangunan yang memerlukan oksigen.

Merujuk pada nilai konsentrasi DO perairan Sungai Siak yang dibandingkan dengan baku mutu Peraturan Pemerintah No. 82 Tahun 2001 Kelas I dan II, diketahui bahwa perairan Sungai Siak di Sekitar Perumahan Sari Residence sudah tidak dapat dipergunakan untuk digunakan sebagai air baku air minum maupun untuk prasarana/sarana rekreasi air, pembudidayaan ikan air tawar, peternakan dan pengairan lahan pertanian.

Hasil pemantauan parameter $\mathrm{pH}$ perairan Sungai Siak di Sekitar Perumahan Sari Residence di tiga stasiun kecuali stasiun 1 dan 5 yang diduga sumber pencemar didapatkan nilai $\mathrm{pH}$ rata-rata, yaitu 5,37 5,41. Merujuk pada baku mutu menurut Peraturan Pemerintah Nomor 82 Tahun 2001 Kelas I dan II yang mensyaratkan $\mathrm{pH}$ perairan dalam rentang $6-9$.

Nilai $\mathrm{pH}$ merupakan parameter yang menunjukkan besarnya konsentrasi ion hidrogen dalam air dan menentukan keseimbangan dinamis antara asam dan basa di dalam air. Nilai $\mathrm{pH}$ menurun akibat dari meningkatnya mineral-mineral bebas asam karbonat, sebaliknya nilai $\mathrm{pH}$ akan meningkat dengan meningkatnya ion-ion karbonat, bikarbonat dan hidroksida. Dari tabel Descriptives nampak bahwa Stasiun 1 yang diduga sebagai sumber pencemar $\mathrm{pH}$ rata-rata sebesar 7,6, Stasiun 2 rata-rata sebesar 5,4133, Stasiun 3 rata-rata sebesar 5,3767, Stasiun 4 rata-rata sebesar 5,3767 dan Stasiun 5 yang juga diduga sumber pencemar rata-rata 8,0433. Dari tabel Test Of Homogeneity Of Variances terlihat bahwa hasil uji menunjukkan bahwa varian ketiga stasiun sama ( $\mathrm{P}$-value $=0,002$ ), sehingga uji anova valid untuk menguji hubungan ini. Hasil uji one way ANOVA yang telah dilakukan mengindikasikan bahwa nilai $\rho=0,000$ lebih kecil daripada nilai kritik $\alpha=0,05$ sehingga ada perbedaan rata-rata $\mathrm{pH}$ berdasarkan kelima stasiun tersebut. Karena hasil uji Anova menunjukkan adanya perbedaan, maka uji selanjutnya adalah melihat stasiun mana saja yang berbeda. Dari Test Of Homogeneity Of Variances menghasilkan bahwa varian kelima stasiun tersebut sama, maka uji lanjut (Post Hoc Test) yang digunakan adalah uji Boferroni untuk menunjukkan adanya perbedaan $\mathrm{pH}$.

Merujuk pada nilai $\mathrm{pH}$ perairan Sungai Siak di Sekitar Perumahan Sari Residence yang dibandingkan dengan baku mutu Peraturan Pemerintah Nomor 82 Tahun 2001 Kelas I dan II, diketahui bahwa perairan Sungai Siak di Sekitar Perumahan Sari Residence tidak dapat dipergunakan untuk digunakan sebagai air baku air minum maupun untuk prasarana/sarana rekreasi air, pembudidayaan ikan air tawar, peternakan dan pengairan lahan pertanian.

Total coliform atau kepadatan coliform merupakan indikator awal bakteri yang digunakan untuk menentukan aman atau tidaknya air untuk dikonsumsi. Hasil penelitian menunjukkan total coliform pada 3 Stasiun Pengamatan di Sungai Siak di Sekitar Perumahan Sari Residence Kota Pekanbaru kecuali stasiun 1 dan 5 yang diduga sebagai sumber pencemar berkisar $11.267 \mathrm{jml} / 100 \mathrm{~mL}$ sampai $15650 \mathrm{jml} / 100 \mathrm{~mL}$ (Gambar 4.6). Stasiun 1 dan 5 di duga merupakan sumber pencemar yang berlokasi di sepanjang parit dan gorong-gorong ke arah sungai Perumahan Sari Residence. Sedangkan Stasiun 2, 3 dan 4 merupakan Stasiun Pengamatan yang berlokasi di perairan Sungai Siak di Sekitar Perumahan Sari Residence Kota Pekanbaru yang di duga tercemar akibat dari Sumber Pencemar yang diduga berada di Stasiun 1 dan 5.

Dari hasil penelitian diketahui bahwa Stasiun 1 yang diduga sebagai sumber pencemar coliform rata-rata sebesar 28266,67 jml/100mL, Stasiun 2 rata-rata sebesar $15650 \mathrm{jml} / 100 \mathrm{~mL}$, Stasiun 3 rata-rata sebesar 12583,33 jml/100mL, Stasiun 4 rata-rata sebesar $11266,67 \mathrm{jml} / 100 \mathrm{~mL}$ dan Stasiun 5 yang juga diduga sumber pencemar rata-rata 56233,33 jml/100mL. Dari tabel Test Of Homogeneity Of Variances terlihat bahwa hasil uji menunjukkan bahwa varian ketiga stasiun sama $(P$-value $=0,046)$. Hasil uji one way ANOVA yang telah dilakukan mengindikasikan bahwa nilai $\rho=0,000$ lebih kecil daripada nilai kritik $\alpha=$ 0,05 sehingga ada perbedaan rata-rata coliform berdasarkan kelima stasiun tersebut. Karena hasil uji Anova menunjukkan adanya perbedaan, maka uji selanjutnya adalah melihat stasiun mana saja yang berbeda. Dari Test Of Homogeneity Of Variances menghasilkan bahwa varian kelima stasiun tersebut sama, maka uji lanjut (Post Hoc Test) yang digunakan adalah uji Boferroni untuk memperlihatkan bahwa semua stasiun yang menunjukkan adanya perbedaan coliform.

Berdasarkan hasil pengamatan di tiga stasiun, kepadatan coliform tertinggi ditemukan di stasiun 5 , yaitu: $56.233 \mathrm{jml} / 100 \mathrm{~mL}$. Lokasi ini di duga sebagai sumber pencemar di mana merupakan lokasi akhir pembuangan limbah domestik melalui gorong-gorong Perumahan Sari Residence yang kemudian dialirkan melalui parit buatan (galian tanah) langsung ke badan sungai. Stasiun 1 juga di duga sebagai sumber pencemar karena Stasiun ini merupakan terusan dari stasiun 5 yang di duga merupakan sumber pencemar 
dari limbah domestik Perumahan Sari Residence melalui gorong-gorong sampai ke stasiun 1 yang merupakan aliran parit buatan (galian tanah) dari Stasiun 5 menuju badan sungai. Angka coliform pada stasiun ini $28.267 \mathrm{jml} / 100 \mathrm{~mL}$.

Selanjutnya berdasarkan hasil pengamatan diperairan Sungai Siak di Sekitar Perumahan Sari Residence Kota Pekanbaru terhadap 5 Stasiun, kepadatan coliform tertinggi ditemukan di Stasiun 2 yang terletak di pinggiran bantaran Sungai Siak sepanjang dan sekitar Perumahan Sari Residence, yaitu 15.650 jml/100mL. Lokasi ini merupakan lokasi pemukiman padat penduduk di mana juga terdapat perumahan lain dan pemukiman penduduk disamping Perumahan Sari Residence. Aktifitas manusia yang tinggi di Sungai Siak (Sekitar Perumahan Sari Residence) menyebabkan masuknya buangan-buangan organik seperti limbah domestik ke badan air. Menurut Feliatra (2002), pengaruh limbah rumah tangga seperti feses atau sisa makanan lainnya masih mendominasi sebagai faktor penyebab pencemaran lingkungan air. Lokasi pemukiman padat penduduk dengan kerapatan penduduk yang tinggi, jarak antara satu rumah dengan rumah yang lain sangat dekat, jarak antara pembuangan limbah rumah tangga dan septic tank dengan sumber air cenderung berdekatan serta kebiasaan penduduk di tepian sungai membuang urine dan feses secara langsung ke sungai menyebabkan terjadinya pencemaran bakteri coliform. Atlas (1981) menyatakan bahwa salah satu masalah di perairan sungai adalah adanya buangan air limbah domestik ke dalam perairan.

Total coliform pada stasiun 3 yang berlokasi di sekitar PDAM berada pada nilai $12.583 \mathrm{jml} / 100 \mathrm{~mL}$ yang nilainya lebih rendah dari Stasiun 2. Hal ini juga berhubungan dengan rona lingkungan di mana Stasiun 3 merupakan daerah Hilir Sungai tersebut. Lokasi ini merupakan sumber air baku bagi PDAM disamping beberapa pemukiman penduduk, transportasi air, sarana MCK bagi penduduk sekitar dan terdapat beberapa area perkebunan sawit masyarakat. Air yang berada dislokasi ini cenderung keruh.

Stasiun 4 merupakan lokasi dengan angka total coliform yang tidak jauh berbeda dengan Stasiun 3 namun lebih rendah nilai kepadatan coliform dari stasiun 3 . Hal ini berhubungan dengan rona lingkungan di mana Stasiun 4 merupakan daerah hulu Sungai tersebut dengan jumlah pemukiman penduduk yang lebih sedikit penduduknya di sepanjang sungai dan jalur transportasi air. Angka total coliform Stasiun 4 adalah $11.267 \mathrm{jml} / 100 \mathrm{~mL}$.

Berdasarkan pengukuran yang dilakukan pada semua stasiun pengamatan, suhu air Sungai Siak (Sekitar Perumahan Sari Residence) berkisar antara 31,1 - 31,5 ${ }^{\circ} \mathrm{C}$. Menurut Romimohtarto (1985), suhu perairan Indonesia berkisar antara $27-32^{\circ} \mathrm{C}$. Suhu optimum untuk pertumbuhan bakteri coliform adalah 37 ${ }^{\circ} \mathrm{C}$ (Sayuti et al., 2005; Hidayati et al., 2006). Berdasarkan suhu optimum pertumbuhannya, Supardi dan Sukamto (1999) mengelompokkan bakteri menjadi 3, yaitu : psikrofilik $\left(0-20{ }^{\circ} \mathrm{C}\right)$, mesofilik $\left(20-50{ }^{0} \mathrm{C}\right)$ dan termofilik (50-100 $\left.{ }^{\circ} \mathrm{C}\right)$. Bakteri Coliform yang ditemukan di Sungai Siak (Sekitar Perumahan Sari Residence) Kota Pekanbaru merupakan bakteri kelompok mesofilik dilihat dari suhu air pada saat pengambilan sampel.

Kecerahan di lima stasiun pengambilan sampel tidak menunjukkan variasi yang besar, yaitu antara 39,5 - 44,3 cm tetapi memberikan indikasi rata-rata nilai kecerahan yang relatif kecil. Tingginya bahanbahan yang masuk ke perairan Sungai Siak (Sekitar Perumahan Sari Residence) terutama disekitar Stasiun 2 yang menyebabkan rendahnya kecerahan perairan diprediksi disebabkan oleh dua hal. Pertama karena meningkatnya hunian dan aktivitas yang dilakukan masyarakat di sepanjang bantaran sungai yang disebabkan oleh meningkatnya jumlah penduduk. Kedua meningkatnya intensitas kegiatan industri dan pelayaran. Secara umum peningkatan jumlah penduduk akan memerlukan ruang untuk tempat tinggal dan usaha. Akibat keterbatasan lahan yang tersedia menyebabkan masyarakat menempati wilayah bantaran sungai sehingga mengakibatkan daerah aliran sungai yang berfungsi mengatur tata air menjadi semakin sempit dan cenderung menjadi keruh dan kotor (Hak, 2012).

Meskipun demikian nilai kecerahan perairan Sungai Siak yang relatif rendah juga dipengaruhi oleh faktor alamiah perairan yang mempunyai karakter sumber air berasal dari daerah rawa/gambut. Dimana air yang berasal dari daerah rawa/gambut cenderung berwarna keruh kecoklatan akibat dari kandungan unsur sodium, nitrat, silikat dan zat organik yang cukup tinggi. Tingginya kandungan unsur-unsur tersebut berpengaruh terhadap penetrasi cahaya ke dalam air yang pada akhirnya akan mempengaruhi tingkat kecerahan perairan (Boyd, 1998).

Rendahnya nilai kecerahan perairan Sungai Siak di Sekitar Perumahan Sari Residence juga tidak terlepas dari penurunan kualitas lingkungan di bagian hulu sungai, yaitu alih fungsi lahan menjadi areal perkebunan sawit masyarakat yang menyebabkan terjadinya erosi tanah yang masuk ke dalam perairan Sungai Siak. Dari hasil penelitian yang dilakukan oleh BP-DAS Indragiri Rokan (2005) diketahui bahwa 
erosi yang terjadi di lahan kelapa sawit di DAS Tapung Kiri yang merupakan hulu dari Sungai Siak kurang lebih $70.833 \mathrm{Ton} / \mathrm{Ha} /$ Tahun atau masuk dalam kategori kelas bahaya erosi Sedang (60-180 ton/ha/th). Tingginya nilai erosi di bagian Hulu tentunya akan berpengaruh terhadap nilai kecerahan perairan Sungai Siak. Rendahnya nilai kecerahan tentunya akan berdampak pada terhambatnya intensitas cahaya matahari yang masuk ke dalam tubuh air yang pada akhirnya akan menghambat proses fotosintesis di perairan dan menurunnya konsentrasi DO. Menurut Devi (2000), cahaya matahari akan merusak sel dan menghambat pertumbuhan bakteri coliform.

Effendi (1998) dalam Feliatra (2002), menyatakan bahwa arus dan gelombang dapat membawa bakteri dari satu tempat ke tempat yang lain. Menurut Devi (2000), arus air mempengaruhi distribusi bakteri coliform. Kecepatan arus air Sungai Siak di Sekitar Perumahan Sari Residence berkisar antara 0.07 $0.19 \mathrm{~m} / \mathrm{s}$. Kecepatan arus tertinggi terdapat di stasiun 3 dan 4 .

Faktor lingkungan yang paling sensitif dan berpengaruh terhadap pertumbuhan mikroorganisme khususnya bakteri adalah keberadaan Oksigen. Contohnya, beberapa mikroorganisme dapat tumbuh hanya jika ada $\mathrm{O} 2$ yang disebut aerob obligat. Fakultatif anaerob dapat tumbuh jika tidak ada $\mathrm{O} 2$ tetapi dapat tumbuh lebih baik bila ada O2 (Paco et al., 2003). Oksigen terlarut (Dissolved Oxygen) pada 5 stasiun pengambilan sampel berkisar antara $0,29-2,13 \mathrm{mg} / \mathrm{L}$ yang menunjukkan hasil yang sangat rendah. Merujuk pada nilai baku mutu menurut Peraturan Pemerintah No. 82 Tahun 2001 Kelas I dan II, diketahui bahwa DO perairan Sungai Siak di Sekitar Perumahan Sari Residence sudah tidak memenuhi baku mutu yang ditetapkan. Menurut Pelczar dan Chan (1988), konsentrasi oksigen terlarut tidak terlalu berpengaruh terhadap pertumbuhan bakteri coliform, sebab bakteri ini merupakan bakteri anaerob fakultatif yang dapat hidup dengan ataupun tanpa oksigen.

Bakteri tumbuh dengan baik pada $\mathrm{pH}$ netral (7.0). $\mathrm{pH}$ berpengaruh mempengaruhi metabolisme sel bakteri. Menurut Supardi dan Sukamto (1999), berdasarkan nilai $\mathrm{pH}$ yang dibutuhkan untuk kehidupannya dikenal 3 kelompok mikroorganisme yaitu : Acidofilik yang hidup pada kondisi asam, Mesofilik/Neutrofilik pada $\mathrm{pH}$ normal dan Basofilik yang hidup pada kondisi basa. Bakteri coliform yang terdapat di Sungai Siak (Sekitar Perumahan Sari Residence) Kota Pekanbaru merupakan bakteri mesofilik atau nutrofilik karena pengukuran $\mathrm{pH}$ pada 5 stasiun pengambilan sampel berkisar antara 5,38-8,04.

\section{KESIMPULAN}

Kepadatan bakteri coliform di Sungai Siak (Sekitar Perumahan Sari Residence Kota Pekanbaru) berkisar antara $11267-15650 \mathrm{jml} / 100 \mathrm{~mL}$ dan melewati standar baku mutu air minum serta memerlukan penanganan khusus untuk pemanfaatan air tersebut. Air Sungai Siak (Sekitar Perumahan Sari Residence Kota Pekanbaru) tidak layak untuk di konsumsi sesuai PP No. 82 Tahun 2001 kelas I dan II tentang persyaratan air minum yaitu $1000 \mathrm{jml} / 100 \mathrm{~mL}$ dan $5000 \mathrm{jml} / 100 \mathrm{~mL}$.

\section{UCAPAN TERIMAKASIH}

Penulis menyampaikan terimakasih kepada seluruh pihak yang membantu dalam kelancaran penelitian ini.

\section{DAFTAR PUSTAKA}

Anonim. 201. Air Sungai Siak Tak Layak Minum. http://www.indosiar.com. Diakses 19 Februari 2014.

Atlas, R. M. 1981. Microbial Ecology: Fundamentals and Aplication, Addison Wesley Publishing Company, Rome.

Benoit, R.J. 1971. Self-Purification in Natural Water in L. L. Ciaccio, Water and Water Pollution Handbook, Volume 1, Marcel Dekker, Inc. New York.

Boyd, C.E. 1998. Water Quality in Warmwater Fish Ponds, Fourth Printing, Auburn University Agriculture Experiment Station, Alabama.

BP-DAS Indragiri Rokan. 2005. Rencana Teknik Lapangan Rehabilitasi Lahan dan Konsentrasi Tanah Sub DAS Tapung Kiri dan Tapung Kanan (Sub DAS Siak Hulu), Departemen Kehutanan Direktorat Jenderal Rehabilitasi Lahan dan Perhutanan Sosial. Pekanbaru.

Devi. 2000. Studi Analisis Coliform dan Colifecal pada perairan Sungai Siak di daerah Kota Madya Pekanbaru, dalam Skripsi Fakultas Keguruan dan Ilmu Pendidikan. Universitas Riau. Pekanbaru. 
Effendi, H. 2003. Telaah Kualitas Air Bagi Pengelolaan Sumber Daya Alam dan Lingkungan Perairan. Kanisius. Yogyakarta.

Feliatra. 2002. Sebaran Bakteri E. Coli di Perairan Muara Sungai Bantan Tengah Bengkalis Riau, Laboratorium Mikrobiologi Laut FAPERIKA UNRI, Pekanbaru.

Hak, A. 2012. Kajian Kapasitas Asimilasi Perairan Sungai Rokan Desa Rantau Bais Kabupaten Rokan Hilir Propinsi Riau, dalam Tesis Program Studi Ilmu Lingkungan, Program Pascasarjana Universitas Riau, Pekanbaru (tidak diterbitkan).

Hamidy, R., H. Alawi, Rusliadi dan Elberizon. 1993. Ekosistem Muara Sungai Siak Propinsi Riau : Kondisi Ekologis, Fakultas Perikanan Universitas Riau, Pekanbaru (tidak diterbitkan).

Hidayati, Y.A.; Harlia, E. dan Suryanto, D. 2006. Deteksi Jumlah Total Bakteri dan Coliform pada Kompos Kotoran Domba Sebagai Indikator Sanitasi Lingkungan, Fakultas Peternakan, dalam Lokakarya Nasional Keamanan Pangan Produk Peternakan, Universitas Padjadjaran, Bandung.

Kasry, A. 2005. Air untuk Kehidupan, Makalah dalam Rangka Peringatan Hari Air Sedunia 30 Maret 2005 Provinsi Riau, Pekanbaru.

Paco, R. S.; Leme, I. L.; Bottino, J. A. Dan Ferreira, A. J. P. 2003. Identification of Lactobacillus spp. From Broiler Litter in Brazil, Brazilian Journal of Microbiology, 34 : 236-237.

Putra, A.D. 2009. Pengendalian Erosi Pada Lahan Perkebunan Kelapa Sawit di Sub Das Tapung Kiri, dalam Tesis Program Studi Ilmu Lingkungan, Program Pascasarjana Universitas Riau. Pekanbaru (tidak diterbitkan).

Sayuti, I.; Wulandari, S. dan Fatimah, S. 2005. Bakteri Enterik dalam Minuman Jamu Gendong di Kota Pekanbaru, PMIPA, FKIP, Universitas Riau. Pekanbaru. Biogen. 2(1), 16-19.

Wetzel, R.G. 1975. Limnology. W.B. Saunders Co, Philadelphia. 